\title{
Corporate Governance and Disclosure Quality: Evidence from the Listed Non-Financial Firms of Pakistan
}

\author{
Syed Usman Qadri ${ }^{1 *}$, Ye Chengang ${ }^{2}$, Muhammad Farooq Jamil ${ }^{3}$, Safwan Qadri ${ }^{4}$ \\ ${ }^{I}$ Business School, University of International Business and Economics, Beijing, China \\ ${ }^{2}$ Professor, Department of accounting, Business school, University of International Business and Economics, \\ Beijing, China \\ ${ }^{3}$ Capital University of Science and Technology, Islamabad, Pakistan \\ ${ }^{4}$ School of Political Science and Public Administration, Wuhan University, China
}

*Corresponding Author: Syed Usman Qadri, Business School, University of International Business and Economics, Beijing, China

\begin{abstract}
This study intends to investigate the relationship between corporate governance and disclosure quality. The study uses disclosure index to find out the firm's disclosure quality. For this purpose a sample of eighty firms listed on Karachi Stock Exchange (KSE) for the period of ten years i.e. 2005 to 2014 has been considered. Corporate governance variables tested for this study are the audit committee independence, board size, board independence, CEO duality, family ownership, institutional ownership. To measure the disclosure quality of the individual firms, the study has used the index score and it is checked against the information disclosed in the annual reports. Panel data estimation models have been employed for the purpose of analysis. The results reveal that better disclosure quality of the annual reports in non-financial sector can be achieved by having higher proportion of independent non-executive directors, separate board leadership structure, larger board size, higher the institutional ownership and lower ownership by family members in case of Pakistan.
\end{abstract}

Keywords: Disclosure Quality, Ceo Duality, Audit Committee Independence, Board Size, Board Independence.

\section{INTRODUCTION}

Corporate governance is the scheme of mechanisms, procedure, rules and practices by which corporations are controlled and directed. It also provides the framework for attaining a company's objectives. Berle et al. (1932) and Jensen et al. (1976) come up to the view that corporate governance is assumed to be a fundamental stress between shareholders and corporate managers. Company must follow all the rules, regulations and requirement of the disclosure set by the Securities and Exchange Commission's in order to be listed on major stock exchanges. Ross (1973) describes agency theory in his classical article stated as "The Economic Theory of Agency". Then the theory was properly described by Jensen and Meckling (1976) as principal problems. Companies with good corporate governance also tend to reduce the agency problems between shareholders and managers of the firm and provide long term advantage to the investors and shareholders. Disclosure is the significant mechanism of corporate governance. Wallace and Naser, (1995) raise the point that financial disclosure is an abstract concept and can be measured directly. Companies must disclose good and bad information for fair investing process for the investors. Forker (1992) investigates the link between corporate governance and disclosure quality. The studies found the negative relationship between board size and disclosure quality. Khoshbakht and Mohammad Zadeh Salteh (2011) examine the alliance between the corporate governance mechanisms and the flexible disclosure information in Iranian listed firms over the period from (2002 to 2009). The study found significant relation with the optional disclosure of information and observed insignificant relation between ownership concentration and discretionary disclosure of information

The Companies with good corporate governance also tend to reduce the agency problems between shareholders and managers of the firm and provide long term advantage to the investors and 
shareholders. Wallace and Naser, (1995) raise the point that financial disclosure is an abstract concept and can be measured directly. The Companies must disclose good and bad information for fair investing process for the investors. There is need to inspect whether the disclosure practices taken by the listed companies are sufficient quality and do they satisfy the information needs of the investors. The governance structures in Pakistan are still undergoing changes and investors are less protected. Therefore, the study tries to make connection between corporate governance mechanisms and the disclosure quality in case of Pakistan. The current study intends to answer the following questions:

- Does board size impact disclosure quality?

- Whether board independence impact disclosure quality?

- Does CEO duality impact disclosure quality?

- Whether audit committee independence impact disclosure quality?

- What is the impact of institutional ownership on disclosure quality?

- What is impact of family ownership on disclosure quality?

- Whether managerial ownership impact disclosure quality?

\section{LITERATURE REVIEW}

The corporate Governance and disclosure quality is considered the hot issue for the regulators, analyst, researchers and investors. Researchers like Lung \& Lundholm (2003) figure out a positive bond between the level of information and level of financial disclosure incorporated in annual reports. They also find that, the firms having high quality disclosure was controlled and directed by families and also contain high proportion of independent director and independence of audit committee as well. Marston and Shrives (1991) discuss about the types of information disclose i.e. voluntary disclosure and required disclosure. Bushee and Noe (2001) conjointly supported this argument. Eventually, their results show that there is a positive relationship between institutional ownership and disclosure measurement. One of another literature, Fama and Jensen (1983) studied that any organizations that consist of high number of independent directors in a board have always stronger monitoring and controlling power over managerial decisions. In a board the presence of non-executive directors have confirmed that the effective monitoring power in the board. Arcay and Vazquez (2005) study the link between corporate governance attributes, firm characteristics and extent of voluntary disclosure in Spain. The study has used the independent directors, audit committee, Chairman/CEO duality and board size. Firm size was used as a control variable.

The following discussions provide some explanations that information plays a vital role to play for the disclosure of information to their users. Similarly, Katmun (2012) examines the factors which can influence the disclosure quality of the firm. The study findings established some of the variables in which he concluded that positive and significant relationship between number of board meetings, board independence, audit committee and disclosure quality which also describe the source of information delivered to the end users. More researchers like Khoshbakht and Mohammad et al. (2011) also examine the alliance between the corporate governance mechanisms and the flexible disclosure information in Iranian listed firms over the period 2002 to 2009. The researchers find out a significant relation with the optional disclosure of information and find no significant relation between ownership concentration and discretionary disclosure of information. The results describe that there is negative and weakly associated the double role of CEO with information voluntary disclosure. Effective corporate governance make sure the reliable accounting and high quality financial disclosure, which endow with the transparency of information that allow users especially shareholders and other stakeholder to make effective decisions. Financial reporting of the firms may improve by the existence of independent directors on the board (Peasnell et al., 2000). Moreover, Chen and Jaggi (2000) and Chen Cheung (2004) reported that by inclusion of independent directors on the board may enhance monitoring of the quality of financial disclosures. Earlier research are in the view of positive link between board independence with voluntary disclosure i.e. Adams et al., (1998) and Abdel Salam and Street, (2007), Chen and Jaggi (2000). Moreover, some of researchers in developing economies didn't get significant relationship between the board independence and level of voluntary disclosure. The study of Ho and Wong (2001), Eng and Mak (2003), Leung (2004), Barako et al. (2006), Haniffa and Cooke (2002) and Ghazali and Weetman (2006) found a significant but 
negative link between board independence and the level of voluntary disclosure. In context of Saudi Arabia, Al-Moataz and Hussainey (2010) also reported negative relationship between board independence and corporate voluntary disclosures. Whereas, the study of Ezat and El-Masry (2008), Samaha (2010) and Dahawy (2011) realize the positive connection between voluntary disclosures with board independence. Based on the above argument, the suggested hypotheses are given below:

H1:Higher the number of independent directors in the board has higher level of corporate disclosures.

H2:Higher the number of institutional investors more will be the firm's corporate disclosures.

H3:The board having large number directors tend to have more disclosure of the firm.

H4: Audit committee independence has positive impact on disclosure quality of the firm.

H5: CEO duality impact negatively on disclosure quality of the firm.

H6: Family controlled firms have negatively associated with disclosure quality.

H7: There is negatively an effect of higher levels of managerial ownership on the quality of voluntary disclosure

\section{DATA DESCRIPTION AND METHODOLOGY}

This study contains its investigation to the firms that are working within Pakistan. The study consists of 80 highest capitalized on-financial companies registered on Pakistan stock market from 10 different sectors for the period of 10 years i.e. (2005 to 2014). The data is acquired from diverse sources such as companies and stock market official websites. The design of data comprises only non-financial firms from diverse sectors such as Food \& personal goods, Engineering and Fertilizer industries, Cement, Chemical, Textile, Sugar, Pharmaceutical, Oil and gas exploration, Refinery.

\subsection{Variables Specification}

\subsubsection{Dependent variable: Disclosure Quality (DQ)}

Disclosure index developed for the study is used as a measure of disclosure quality. The maximum score that a company can obtained on this index is 100 . The score are divided into five sub categories which would combine to make an aggregate score for each company i.e. Corporate Objectives (6 points) Director's Report (24 points), Disclosure Score (18), Stakeholder's Information (20 points), Corporate Governance (32 points); Safia Nosheen, (2012).

\subsection{Independent Variables}

Board size is calculated by the number of directors in the board (Kurawa \& ishaku, 2014)

Board independence is measured by the percentage of independent directors in the board (Iqbal, 2013)

CEO duality means that chief executive officer work as the chairman of the board. It is coded as dummy, (1) if CEO has dual role and (0) otherwise.

Institutional ownership is calculated by the percentage of shares acquire by institutional investor.

Audit Committee Independence (ACI)is measured by the number of non-executive directors on audit committee divided by the total number of directors on audit committee (Shah, Butt, \& Hasan, 2009).

Family ownership (FMO) is measured by percentage of shares held by family members.

Managerial ownership (MGO) is measured by percentage of shares held by manager of the firm.

\subsection{Control Variables}

Firm Size (FS) Calculated by log of total assets (Chiraz Ben Ali, 2004; Abor, 2007; pham et al,. 2007).

Leverage (Lev) is measured by debt to equity ratio (Chiraz Ben Ali, 2004).

Sale Growth (SGrwth) is measured by (Current Period Net Sales - Previous Period Net Sales) divided by Previous Period Net Sales * 100)

To provide evidence of the impact of corporate governance attribute on disclosure practices this study used the following multiple regression equation: 
Corporate Governance and Disclosure Quality: Evidence from the Listed Non-Financial Firms of Pakistan

$D I S C L_{i, t}=\beta_{0}+\beta_{1} B S_{i, t}+\beta_{2} B I_{i, t}+\beta_{3} C E O D_{i, t}+\beta_{4} F_{M O}+\beta_{i, t}+\beta_{5} A C I_{i, t}+\beta_{6} I N S T O_{i, t}+\beta_{7} M G O+\beta_{8} F S_{i, t}+$ $\beta_{g} \operatorname{Lev}_{i, t}+\beta_{10} S G R W T H+\varepsilon_{i, t}$ ....(i)

The existing study works initially on the data of 100 high capitalized firms. This study used the OLS, panel data technique for the analysis of the result. In panel data, we can observe different cross sectional units for several years, which can be pooled together; this will permit us to increase the sample size. Hence, panel data technique is best technique where both time series and cross sectional data at same time can be estimated.

\section{RESUltS AND DisCUSSION}

This section includes correlation matrix, descriptive statistics, and regression analysis.

\subsection{Correlation Matrix}

The main reason of correlation is the indication of the relation between two variables or to study whether the two variables move in similar or opposite directions. This technique also deals regarding the strength and trend of connection among variables. The result from the correlation matrix is given below in the table (1).

Table1. Correlation Matrix

\begin{tabular}{|l|l|l|l|l|l|l|l|l|l|l|l|}
\hline & DI & ACI & BI & BS & CEOD & FMO & INSTO & GMO & LEV & FS & GROW \\
\hline DI & 1 & & & & & & & & & & \\
\hline ACI & 0.005 & 1 & & & & & & & & & \\
\hline BI & 0.063 & 0.05 & 1 & & & & & & & & \\
\hline BS & 0.025 & 0.21 & 0.08 & 1 & & & & & & & \\
\hline CEOD & -0.25 & 0.05 & -0.30 & 0.12 & 1 & & & & & & \\
\hline FMO & -0.02 & 0.08 & 0.002 & 0.06 & -0.02 & 1 & & & & & \\
\hline INSTO & 0.020 & 0.11 & 0.13 & 0.02 & -0.03 & -0.15 & 1 & & & & \\
\hline MGO & -0.15 & 0.15 & -0.19 & -0.01 & -0.04 & 0.433 & -0.08 & 1 & & & \\
\hline LEV & -0.04 & 0.18 & -0.10 & 0.002 & 0.10 & 0.16 & 0.006 & 0.16 & 1 & & \\
\hline FS & -0.17 & 0.07 & 0.09 & 0.04 & 0.10 & 0.11 & -0.08 & -0.02 & 0.02 & 1 & \\
\hline SGROW & -0.005 & 0.01 & 0.02 & 0.02 & 0.04 & 0.01 & 0.04 & 0.01 & 0.01 & 0.005 & 1 \\
\hline
\end{tabular}

Table (1) displays the correlation between the variables. Variables are positively and negatively correlated with each other. The variables audit committee independence, board independence, board size and institutional investor's showing the positive sign with the disclosure. While the variables CEO duality, family ownership, managerial ownership showing the negative sign with disclosure quality. Moreover the control variables leverage, firm size and sales growth also shows negative relation on the disclosure quality.

\subsection{Descriptive Statistics}

It is used to get the feel of data. It includes, mean, median, standard deviation, minimum and maximum, skewness, and kurtosis.

Table2. Descriptive Statistics

\begin{tabular}{|l|l|l|l|l|l|l|l|}
\hline Variables & Mean & Median & Maximum & Minimum & Std. Dev. & Skewness & Kurtosis \\
\hline DI & 61.438 & 62.6 & 82.8 & 34 & 9.273 & -0.259 & 2.789 \\
\hline ACI & 0.644 & 0.670 & 0.830 & 0.330 & 0.124 & -1.457 & 4.444 \\
\hline BI & 0.654 & 0.700 & 0.930 & 0.130 & 0.188 & -0.738 & 2.970 \\
\hline BS & 8.428 & 8.000 & 14.00 & 4.000 & 1.718 & 1.117 & 3.978 \\
\hline CEOD & 0.262 & 0.000 & 1.000 & 0.000 & 0.440 & 1.077 & 2.161 \\
\hline FS & 17.047 & 16.690 & 24.660 & 12.010 & 2.599 & 0.957 & 3.452 \\
\hline MGO & 4.513 & 0.000 & 75.22 & 0.000 & 13.505 & 3.527 & 15.315 \\
\hline INSTO & 0.086 & 0.070 & 0.350 & 0.000 & 0.068 & 0.913 & 3.306 \\
\hline LEV & 0.254 & 0.180 & 0.970 & 0.010 & 0.218 & 1.230 & 3.654 \\
\hline FMO & 0.73 & 0.000 & 44.29 & 0.000 & 4.910 & 8.073 & 69.24 \\
\hline SGROW & 0.131 & 0.15 & 1.19 & -1.92 & 0.210 & -2.327 & 26.85 \\
\hline Cross-sections & 80 & 80 & 80 & 80 & 80 & 80 & 80 \\
\hline Observations & 800 & 800 & 800 & 800 & 800 & 800 & 800 \\
\hline
\end{tabular}


Table (2) indicates the results that the average disclosure score of high capitalized firm listed in Pakistan is 61.43. It shows that the high capitalized firms in Pakistan disclose more information to the users.

\subsection{Regression Analysis}

The regression analysis shows the link between corporate governance and disclosure quality in eighty (80) high capitalized firms listed in Karachi stock exchange. For the purpose of analysis, panel regression is used. Panel data analysis consists of common effect model, fixed effect model and random effect model. The results of the tests are given below in Table (3).

Table3. Common effect model

\begin{tabular}{|l|l|l|l|l|}
\hline Variable & Coefficient & Std. Error & t-Statistic & Prob. \\
\hline C & 4.143766 & 0.053909 & 76.86618 & 0.0815 \\
\hline ACI & -0.047838 & 0.045837 & 1.043663 & 0.2970 \\
\hline BI & 0.032044 & 0.030038 & 1.066757 & 0.2864 \\
\hline BS & 0.004315 & 0.003292 & 1.310877 & 0.1903 \\
\hline CEOD & -0.090629 & 0.012802 & 7.079153 & 0.0000 \\
\hline FMO & -0.158958 & 0.060528 & 2.626165 & 0.0088 \\
\hline FS & -0.003190 & 0.002165 & 1.473518 & 0.1410 \\
\hline MGO & -0.117998 & 0.041752 & 2.826141 & 0.0048 \\
\hline INSTO & -0.010263 & 0.081308 & 0.126225 & 0.8996 \\
\hline LEV & 0.065746 & 0.025061 & 2.623378 & 0.0089 \\
\hline SGROW & -0.000217 & 0.015455 & 0.014062 & 0.9888 \\
\hline Adjusted R-squared & & 0.095498 & & \\
\hline F-statistic & & 8.654145 & & \\
\hline Prob (F-statistic) & 0.000 & & \\
\hline Durbin-Watson stat & 0.91817 & & \\
\hline Cross sections & & 80 & & \\
\hline Observations & & 800 & & \\
\hline
\end{tabular}

The table (3) can be discussed as the adjusted R-square of the common effect model is 0.09 , which means that only 9.5 unit changes in dependent variable is explained by independent variables. While in the above table, the variable audit committee independence (ACI) has negative and insignificant relationship with disclosure quality. Similarly, the variables board independence (BI) and board size (BS) have positive but insignificant relationship with the disclosure quality. However, CEO Duality, Family ownership (FMO) and managerial ownership (MGO) have negative but significant relationship with the disclosure quality. While, institutional ownership (INSTO) has negative and insignificant relationship with disclosure quality. Moreover, the control variables leverage (LEV) has positive and significant relationship while the variables firm size (FS) and sales growth (SGROW) have both negative and insignificant relationship with disclosure quality.

\subsection{Fixed Effect Model}

Table (4) indicates that the adjusted R-squared of fixed effect model is, which means that 0.81 unit variation in dependent variable is explained by independent variables.

Table4. Fixed effect model

\begin{tabular}{|l|l|l|l|l|}
\hline \multicolumn{1}{|c|}{ Variable } & Coefficient & Std. Error & t-Statistic & Prob. \\
\hline C & 0.364706 & 0.073924 & 49.33486 & 0.0628 \\
\hline ACI & 0.292132 & 0.069473 & 4.204972 & 0.0003 \\
\hline BI & 0.126718 & 0.031805 & 3.984210 & 0.0001 \\
\hline BS & -0.007285 & 0.003543 & 2.056015 & 0.0401 \\
\hline CEOD & -0.192947 & 0.014815 & 1.302503 & 0.1932 \\
\hline FMO & -0.019546 & 0.036687 & -0.53277 & 0.5944 \\
\hline FS & 0.014982 & 0.002765 & 5.417724 & 0.0000 \\
\hline MGO & 0.162776 & 0.108618 & 1.498612 & 0.1344 \\
\hline INSTO & 0.053383 & 0.051986 & 1.026876 & 0.3048 \\
\hline LEV & -0.05071 & 0.020913 & -2.42476 & 0.0156 \\
\hline SGROW & -0.00111 & 0.007483 & -0.14948 & 0.8812 \\
\hline
\end{tabular}


Corporate Governance and Disclosure Quality: Evidence from the Listed Non-Financial Firms of Pakistan

\begin{tabular}{|l|l|l|l|l|}
\hline Adjusted R-squared & & 0.419042 & & \\
\hline F-statistic & & 41.12143 & & \\
\hline Prob (F-statistic) & & 0.000000 & & \\
\hline Durbin-Watson stat & & 1.428479 & & \\
\hline Crossections & & 80 & & \\
\hline Observation & & 800 & & \\
\hline
\end{tabular}

In the above table variables, audit committee independence (ACI) and board independence (BI) have positive and significant relationship with disclosure quality while Board size (BS), has negative but significant relationship. Moreover, family ownership (FMO) has negative and insignificant relationship. While, CEO Duality, managerial ownership (MGO), institutional ownership (INSTO) have positive but insignificant relationship with disclosure quality. In the case of control variables firm size (FM) has positive and significant relation and leverage (LEV) has negative but significant relation and sale growth (SGROW) has negative and significant relation with disclosure quality. After the sort out the result of common and fixed effect model now to check whether common or fixed model would be appropriate, as both models have different assumption to be selected. For this we have to run likelihood ratio test which have null and alternate hypothesis.

\subsection{Likelihood Ratio Test (F-test)}

This test is used to check which model is appropriate, common or fixed model.

Table5. Likelihood ratio test (F-test)

\begin{tabular}{|l|l|l|l|}
\hline Effects Test & Statistic & d.f. & Prob. \\
\hline Cross-section F & 40.825012 & $(79,708)$ & 0.000 \\
\hline Cross-section Chi-square & 1370.091980 & 80 & 0.000 \\
\hline
\end{tabular}

From table (5), the probability of cross section is significant, which means that the study accept alternative hypothesis and reject the null hypothesis, which means that the appropriate model is fixed effect model as the probability value is less than 5\% significant level. Moving towards the Hausman test, the study must have to estimate the random effect model to choose the appropriate model between fixed and random effect model.

\subsection{Random Effect Model}

Table (6) explains that the adjusted R-squared of Random effect model is 0.094 which means that 0.094 unit variation in dependent variables which is explained by explanatory variables.

Table6. Random effect model

\begin{tabular}{|l|l|l|l|l|}
\hline Variable & Coefficient & Std. Error & t-Statistic & Prob. \\
\hline C & 0.375025 & 0.068670 & 54.68185 & 0.0796 \\
\hline ACI & 0.209172 & 0.061154 & 3.420431 & 0.0007 \\
\hline BI & 0.125165 & 0.030026 & 4.168594 & 0.0000 \\
\hline CESD & -0.005251 & 0.003332 & 1.576012 & 0.1154 \\
\hline FMO & -0.001783 & 0.013796 & 0.129227 & 0.8972 \\
\hline FS & -0.024221 & 0.036292 & 0.667379 & 0.5047 \\
\hline MGO & 0.011570 & 0.002539 & 4.557245 & 0.0000 \\
\hline INSTO & 0.009162 & 0.078624 & 0.116530 & 0.9073 \\
\hline LEV & 0.047665 & 0.051191 & 0.931105 & 0.3521 \\
\hline SGROW & -0.043479 & 0.020203 & 2.152111 & 0.0317 \\
\hline Adjusted R-squared & -0.000898 & 0.007460 & 0.120423 & 0.9042 \\
\hline F-statistic & & 0.094111 & & \\
\hline Prob(Fstatistic) & & 7.432728 & & \\
\hline Durbin-Watson Stat & & 0.00000 & & \\
\hline Cross sections & 1.43756 & & \\
\hline Observations & & 80 & & \\
\hline
\end{tabular}

In the above table the variables, audit committee independence (ACI) and board independence (BI) and whereas board size, CEO duality, family ownership (FMO) have negative but insignificant relationship with the disclosure quality, which shows that it can affect the firm disclosure quality 
performance. Moreover, the variables managerial ownership (MGO) and institutional ownership (INSTO) have negative and insignificant relationship. In the case of control variables firm size (FS) has positive significant relationship with disclosure quality. While, leverage (LEV) and sales growth have negative sign but leverage show significant and sales growth shows insignificant relationship on the disclosure quality. The study carries out the Hausmen test to select the suitable model between fixed and random effects.

\subsection{Hausman Test}

Table (7) indicates that the null hypothesis of the hausman test in random effect is consistent and efficient and the alternative hypothesis in random effect is inconsistent, so fixed effect is more suitable.

Table7. Hausman test

\begin{tabular}{|c|c|c|c|}
\hline Test Summary & Chi-Sq. Statistic & Chi-Sq. d.f & Prob. \\
\hline Cross-section random & 41.122089 & 11 & 0.0000 \\
\hline
\end{tabular}

Form table (7) results, it is cleared that the value of the probability is significant and less than the 5\% significant level, hence the study accept the alternative hypothesis and reject the null hypothesis, indicating that the best appropriate model is fixed effect model.

\subsection{Discussion of Results}

The main purpose of this result discussion, as to ensure our results is consistent with the previous studies. The variable board independence has showed positive and significant relationship with the disclosure quality and indicating that when there is 1 unit change in board's independence may bring the change in the result of disclosure quality by 12 units respectively. So from the given discussion we accept our second hypothesis that is $\mathrm{H} 2$ : higher the level of size of the independent directors in a firm's board may result in higher level of corporate disclosure. The variable board size explains significant and negative impact on disclosure quality of the firms and indicating that with 1 unit change in board size may bring the result of 0.7 unit decrease in disclosure quality. . Hence, from the above findings we accept our $\mathrm{H} 3$ : hypothesis that is board size and disclosure quality has the negatively related with each other. Furthermore, the variable CEO duality has negative and significant relationship with the disclosure quality. It is indicating that when chief executive has also the role of chairman in the company, and if it is increasing by 1 unit then the company disclosure quality may reduce to 19 units. The hypothesis $\mathrm{H} 4$ is that CEO duality finds negative impact on disclosure practices. Moreover, the variable family ownership shows negative and insignificant on the disclosure quality. The coefficient -0.019 means that one percent 1 unit increase in the managerial ownership there is 0.019 decreases in the disclosure quality of the firms. Additionally, the variable institutional ownership shows positive and insignificant impact on the firm disclosure quality. So therefore, we accepted our hypothesis as well i.e. the firm having higher proportion of institutional investors showing the positive relationship with the disclosure quality of the firm.

The study also includes some control variables like firm size which has positive and significant impact on the disclosure quality of the firm. The coefficient 0.014 describe that when 1 unit change in firm size there is increaseof 0.014 in disclosure quality of the firm. Leverage which is showed negative and significant impact on the disclosure quality and coefficient -0.05 means that 1 unit change in leverage reduces the disclosure quality level of the firm, while the variable sales growth showing negative but insignificant relationship with the disclosure quality and coefficient -0.001 means that when there is 1 unit change in sales growth of the firm it will decrease the level of disclosure by 0.001 .

\section{CONCLUSION AND RECOMMENDATION}

\subsection{Conclusion}

This research study endows with the relation between corporate governance and disclosure quality of the eighty (80) high capitalize non-financial firms which are listed on KSE-100 index of Pakistan (currently known as Pakistan stock exchange). For this purpose, the studies use disclosure score to find out the disclosure quality of the individual firm. The research uses disclosure quality as a dependent variable and corporate governance attributes as independent variables i.e. audit committee 
independence, board size, board independence, CEO duality, family ownership, institutional ownership, managerial ownership and also use some of the control variables growth sales, leverage and firm size. The results of the study prove that the board's and ownership structure significantly affecting the disclosure quality of the company.

According to the study, the company's board of directors should at least consist of $50 \%$ independent directors, also reduce their board size to eight to ten members and the chairman of the board should not have duality in the job i.e. chairman should not be the CEO in the same company. Also, audit committee independence plays a crucial role while disclosing the company information to the investors and committee must include independent directors in the audit committee. Whereas, the institutional ownership is the important shareholders, who proved that they are the monitors over the management of the company, therefore; they should have to maintain a good level of ownership in the company. The variables family ownership and managerial ownership have insignificant effect on the disclosure quality. As in Pakistan, most of the shares are in the hand of families so they are making decisions which are in the best interest of themselves rather than the interest of shareholders. While, the variables leverage and sales growth have negative effect on disclosure quality and firm size has positive and significant impact on firm disclosure quality.

The study suggests that every listed company must have more independent directors on their board, so that decision making are made independently in the best concern of all shareholders, and also agency problems between management and shareholders could be reduce to appropriate level. Audit committee independence has more influence on disclosing information to the public, it must be contains independent directors in the committee. Similarly, institutional ownership or shareholders like financial institutions is the active shareholders that monitor the activities of a firm. It also plays a role of watch dogs over management activities.

\subsection{Direction for Future Research}

The current study only considered those companies which are listed on Pakistan stock exchange. The study can be extended to the Asian growing economies and compare the results with respect to different countries level. Furthermore, the study also contain just non-financial companies data, so in future a comparable study can be conducted where at one end a sample of financial companies can be taken and at the other end non-financial companies can be used.

\subsection{List of Abbreviation}

$\mathrm{DISCL}=$ Disclosure quality, $\mathrm{BS}=\mathrm{Board}$ size, $\mathrm{BI}=\mathrm{Board}$ independence, $\mathrm{CEOD}=\mathrm{CEO}$ duality, $\mathrm{ACI}=$ Audit committee independence, FMO = Family Ownership, MGO = Managerial Ownership, INSTO $=$ Institutional ownership, FS $=$ Firm size, LEV= Leverage, SGRWTH= Sales Growth, $\varepsilon=$ Error term

\subsection{Availability of data and material}

All the data of this research was collected from annual reports of companies, Pakistan stock exchange and State bank of Pakistan data sources.

\section{ACKNOWLEDGEMENT}

This research is sponsored in part by an important project of National Social Science fund of China under the project title "Innovation research on national Governance, State audit system and anticorruption system,"(13AZD002), chair, in 2013.

\section{REFERENCES}

[1] Abdelsalam, O. H., \& Street, D. L. (2007). Corporate governance and the timeliness of corporate internet reporting by UK listed companies. Journal of International Accounting, Auditing and Taxation, 16(2), 111-130.

[2] Adams, C. A., Hill, W. Y., \& Roberts, C. B. (1998). Corporate social reporting practices in Western Europe: legitimating corporate behaviour. The British accounting review, 30(1), 1-21.

[3] Arcay, M. R. B., \& Vazquez, M. F. M. (2005). Corporate characteristics, governance rules and the extent of voluntary disclosure in Spain. Advances in Accounting, 21, 299-331.

[4] Barako, D. G., Hancock, P., \& Izan, H. Y. (2006). Factors influencing voluntary corporate disclosure by Kenyan companies. Corporate Governance: an international review, 14(2), 107-125. 
[5] Berle, A. A., \& Means, G. C. (1932). The modern corporation and private property. New York: Macmillan.

[6] Bushee, B. J., \& Noe, C. F. (2000). Corporate disclosure practices, institutional investors, and stock return volatility. Journal of accounting research, 171-202.

[7] Chen, C. J., \& Jaggi, B. (2000). Association between independent non-executive directors, family control and financial disclosures in Hong Kong. Journal of Accounting and Public policy, 19(4-5), 285-310.

[8] Chang, H. J., Lin, S. J., Murray, L. W., Efendioglu, A. M., Khoshbakht, H., \& Salteh, H. M. (2011). Entre preneurial intensity in catering Industry: A case study on wang group in Taiwan. Business and Management Review, 1(9), 1-12.

[9] Chen, S., Sun, S. Y., \& Wu, D. (2010). Client importance, institutional improvements, and audit quality in China: An office and individual auditor level analysis. The Accounting Review, 85(1), 127-158.

[10] Core, J. E. (2001). A review of the empirical disclosure literature: discussion. Journal of Accounting and Economics, 31(1), 441-456.

[11] Eng, L. L., \& Mak, Y. T. (2003). Corporate governance and voluntary disclosure. Journal of accounting and public policy, 22(4), 325-345.

[12] Ezat, A., \& El-Masry, A. (2008). The impact of corporate governance on the timeliness of corporate internet reporting by Egyptian listed companies. Managerial finance, 34(12), 848-867.

[13] Fama, E. F., \& Jensen, M. C. (1983). Separation of ownership and control. The journal of law and Economics, 26(2), 301-325.

[14] Forker, J. J. (1992). Corporate governance and disclosure quality. Accounting and Business research, 22(86), 111-124.

[15] Ghazali, N. A. M., \& Weetman, P. (2006). Perpetuating traditional influences: Voluntary disclosure in Malaysia following the economic crisis. Journal of International Accounting, Auditing and Taxation, 15(2), 226-248.

[16] Gul, F. A., \& Leung, S. (2004). Board leadership, outside directors' expertise and voluntary corporate disclosures. Journal of Accounting and public Policy, 23(5), 351-379.

[17] Haniffa, R. M., \& Cooke, T. E. (2002).Culture, corporate governance and disclosure in Malaysian corporations. Abacus, 38(3), 317-349

[18] Ho, L. P., Tower, G., \&Barako, D. (2008). Improving governance leads to improved corporate communication. Corporate Ownership \& Control, 5(4), 26-33.

[19] Ho, S. S., \& Wong, K. S. (2001). A study of the relationship between corporate governance structures and the extent of voluntary disclosure. Journal of International Accounting, Auditing and Taxation, 10(2), 139-156.

[20] Htay, S. N. N., Mohd Said, R., \& Salman, S. A. (2013). Impact of corporate governance on disclosure quality: empirical evidence from listed banks in Malaysia. International Journal of Economics and Management, 7(2), 242-279.

[21] Jensen, M. C., \& Meckling, W. H. (1976). Theory of the firm: Managerial behavior, agency costs and ownership structure. Journal of financial economics, 3(4), 305-360.

[22] Karami, G., Hajiazimi, F., \&Attaran, N. (2012).Accounting Disclosure Quality and Bankruptcy Prediction. International Journal of Business and Social Research, 2(4), 283-294.

[23] Khodadadi, V., Khazami, S., \& Aflatooni, A. (2010).The effect of corporate governance structure on the extent of voluntary disclosure in Iran. Business Intelligence Journal, 3(2), 151-164

[24] Li, J., Pike, R., \& Haniffa, R. (2008). Intellectual capital disclosure and corporate governance structure in UK firms. Accounting and Business Research, 38(2), 137-159.

[25] Liang, J. W., Lin, M. F., \& Chin, C. L. (2012). Does foreign institutional ownership motivate firms in an emerging market to increase voluntary disclosure? Evidence from Taiwan. Review of Quantitative Finance and Accounting, 39(1), 55-76.

[26] Marston, C. L., \& Shrives, P. J. (1991). The use of disclosure indices in accounting research: a review article. The British Accounting Review, 23(3), 195-210.

[27] Peasnell, K. V., Pope, P. F., \& Young, S. (2005). Board monitoring and earnings management: Do outside directors influence abnormal accruals?. Journal of Business Finance \& Accounting, 32(7-8), 1311-1346.

[28] Ross, S. A. (1973). The economic theory of agency: The principal's problem. The American Economic Review, 63(2), 134-139.

[29] Samaha, K., \& Dahawy, K. (2010). An empirical analysis of corporate governance structures and voluntary corporate disclosure in volatile capital markets: The Egyptian experience. International Journal of Accounting, Auditing and Performance Evaluation, 7(1-2), 61- 93. 
Corporate Governance and Disclosure Quality: Evidence from the Listed Non-Financial Firms of Pakistan

[30] Samaha, K., Dahawy, K., Hussainey, K., \& Stapleton, P. (2012). The extent of corporate governance disclosure and its determinants in a developing market: The case of Egypt. Advances in Accounting, 28(1), 168-178.

[31] Velashani, B., \& Ali, M. (2009). Financial Reporting Gap in Developing Countries: The Case Study of Iran. Middle Eastern Finance and Economics,3.

[32] Wallace, R. O., \&Naser, K. (1996). Firm-specific determinants of the comprehensiveness of mandatory disclosure in the corporate annual reports of firms listed on the stock exchange of Hong Kong. Journal of Accounting and Public policy, 14(4), 311-368.

[33] Zaheer, N. (2013). Effects of Duality, Board Size and Board Composition on Corporate Governance Disclosure in Pakistan. International SAMANM Journal of Finance and Accounting, 1(3), 1-16.

\section{ANNEXURE I}

\section{Disclosure Score Measurement}

\begin{tabular}{|c|c|c|}
\hline NO & Title & Score \\
\hline 1 & Corporate objectives & \\
\hline 1.1 & Mission & 1 \\
\hline 1.2 & Vision & 1 \\
\hline 1.3 & Overall strategic objectives & 1 \\
\hline 1.4 & Core Values & $\mathbf{1}$ \\
\hline 1.5 & Code of conduct/ethical principle/statement of ethics & 1 \\
\hline 1.6 & History of the company/profile & 1 \\
\hline & Total & 6 \\
\hline 2 & Director's Report/chairman's/CEO overview & \\
\hline 2.1 & $\begin{array}{l}\text { Performance review of the company (for detailed disclosure more weight age should be } \\
\text { given) }\end{array}$ & 4 \\
\hline 2.2 & $\begin{array}{l}\text { Disclosing the Business risks and challenges that company is facing and steps taken to } \\
\text { mitigate such risks in future }\end{array}$ & 4 \\
\hline 2.3 & A general review of the future prospects, outlook and plans for expansion & 3 \\
\hline 2.4 & Business process reengineering/development activities & 1 \\
\hline 2.5 & Disclosure of the contribution of the company to the national exchequer of the country & 1 \\
\hline 2.6 & $\begin{array}{l}\text { Contribution towards the development of human capital i.e. work force planning, staff } \\
\text { training etc }\end{array}$ & 2 \\
\hline 2.7 & How corporate social responsibilities, environmental issues been met & 2 \\
\hline 2.8 & Market share information & 1 \\
\hline 2.9 & $\begin{array}{l}\text { Disclosing how liquidity problems been solved and the company's plan to manage its } \\
\text { repayment of debts and recover losses }\end{array}$ & 2 \\
\hline 2.10 & Information regarding different segments and units of the company & 2 \\
\hline 2.11 & Safety of the employees & 2 \\
\hline & Total & 24 \\
\hline 3 & Disclosure & \\
\hline 3.1 & Financial Reporting Results & 1 \\
\hline 3.2 & Accounting standards used for the accounts & 1 \\
\hline 3.3 & Comprehensive related party disclosure & 1 \\
\hline 3.4 & Disclosure of all changes in corresponding figures & 1 \\
\hline 3.5 & Adequate disclosure of significant judgment and estimates & 1 \\
\hline 3.6 & Detailed disclosure of Financial instruments & 1 \\
\hline 3.7 & Further disclosure of facilities provided to CEO and Directors & 1 \\
\hline 3.8 & Detailed disclosure of all contingencies and commitments & 1 \\
\hline 3.9 & Adequate disclosure of new accounting standard and their expected impact & 1 \\
\hline 3.10 & Detailed capacity disclosure & 1 \\
\hline 3.11 & Segmental analysis & 1 \\
\hline 3.12 & Cash flow statement based on direct method & 1 \\
\hline 3.13 & Disclosure of fair value of property, plant and equipment & 1 \\
\hline 3.14 & Adequate disclosure of change in accounting policy & 1 \\
\hline 3.15 & Expenditure on Research and development & 1 \\
\hline 3.16 & Information on Auditors & 1 \\
\hline 3.17 & Disclosure of how much is paid to Auditors for consulting and other work & 1 \\
\hline 3.18 & Number of employees & 1 \\
\hline
\end{tabular}


Corporate Governance and Disclosure Quality: Evidence from the Listed Non-Financial Firms of Pakistan

\begin{tabular}{|c|c|c|}
\hline & Total & 18 \\
\hline \multirow[t]{2}{*}{4} & Stake holder's Information & \\
\hline & Information relevant for shareholders and other users of financial statements & \\
\hline 4.1 & Investor information for 6 years & 10 \\
\hline 1 & Gross profit ratio & 0.4 \\
\hline 2 & EBITDA Margin to sales & 0.4 \\
\hline 3 & Net profit to sales & 0.4 \\
\hline 4 & Return on equity & 0.4 \\
\hline 5 & Return on capital employed & 0.4 \\
\hline 6 & Weighted average cost of debt & 0.4 \\
\hline 7 & Inventory turnover ratio/No of days in inventory & 0.4 \\
\hline 8 & Debtor turnover ratio/ No of days in receivable & 0.4 \\
\hline 9 & Creditor turnover ratio/ No of days in payables & 0.4 \\
\hline 10 & Operating cycle & 0.4 \\
\hline 11 & Total assets turnover ratio/ Fixed assets turnover ratio & 0.4 \\
\hline 12 & Current ratio & 0.4 \\
\hline 13 & Quick / Acid test ratio & 0.4 \\
\hline 14 & Price earnings ratio & 0.4 \\
\hline 15 & Cash dividend per share & 0.4 \\
\hline 16 & Bonus shares issued & 0.4 \\
\hline 17 & Dividend yield ratio & 0.4 \\
\hline 18 & Dividend payout ratio & 0.4 \\
\hline 19 & Dividend cover ratio & 0.4 \\
\hline 20 & Debt: equity ratio & 0.4 \\
\hline 21 & Interest cover ratio & 0.4 \\
\hline 22 & $\begin{array}{l}\text { Breakup value per share without including the effect of surplus on revaluation of fixed } \\
\text { assets }\end{array}$ & 0.4 \\
\hline 23 & Breakup value per share including the effect of surplus on revaluation of fixed assets & 0.4 \\
\hline 24 & Market value per share at the end of the year & 0.4 \\
\hline 25 & EBTIDA & 0.4 \\
\hline & Total & 10 \\
\hline 4.2 & Summary of cash flow statements for six year & 1 \\
\hline & Shareholders information & \\
\hline 4.3 & Shares held by sponsors / directors/ executive & 1 \\
\hline 4.4 & Vertical horizontal analysis of balance sheet and profit and loss account for 6 years & 4 \\
\hline 4.5 & $\begin{array}{l}\text { Statement of value added distributed to employees, government, shareholders, } \\
\text { creditors, society and business }\end{array}$ & 4 \\
\hline & Total & 20 \\
\hline 5 & Corporate Governance & \\
\hline 5.1 & Date of authorization of financial statements by the Board of directors & 10 \\
\hline & Within 45 days (10 marks) & \\
\hline & Within 60 days ( 7 marks) & \\
\hline & Within 75 days (4 marks) & \\
\hline 5.2 & $\begin{array}{l}\text { Statement of compliance with the best practice of code of corporate governance (No } \\
\text { marks in case of other than clean review report) }\end{array}$ & 1 \\
\hline 5.3 & The board structure and its committees & 1 \\
\hline 5.4 & Chairman of the board other than CEO & 1 \\
\hline 5.5 & $\begin{array}{l}\text { Information on the Board committees and their terms of references and number of } \\
\text { meetings held }\end{array}$ & \\
\hline $\mathbf{A}$ & Information on the Board committees & \\
\hline B & Terms of references & \\
\hline $\mathbf{C}$ & Number of meetings held & \\
\hline 5.6 & Role and function of the board of directors & 2 \\
\hline 5.7 & Salient features of the audit committee charter/terms of reference & 1 \\
\hline 5.8 & Name of independent Directors /Non executive's directors to be disclosed & 1 \\
\hline 5.9 & Disclose for all members of board of directors & 2 \\
\hline A & Profile of each director & \\
\hline B & $\begin{array}{l}\text { Involvement /engagement of each director in their companies/entities as CEO, } \\
\text { director, CFO, or trustee etc. }\end{array}$ & \\
\hline
\end{tabular}


Corporate Governance and Disclosure Quality: Evidence from the Listed Non-Financial Firms of Pakistan

\begin{tabular}{|l|l|l|}
\hline $\mathbf{5 . 1 0}$ & $\begin{array}{l}\text { Non executive directors on the audit committee (full marks if all are non- executive } \\
\text { directors, else zero) }\end{array}$ & $\mathbf{2}$ \\
\hline $\mathbf{5 . 1 1}$ & Name list of board attendance & $\mathbf{2}$ \\
\hline $\mathbf{5 . 1 2}$ & Training and development activities for directors & $\mathbf{2}$ \\
\hline $\mathbf{5 . 1 3}$ & Organizational chart & $\mathbf{1}$ \\
\hline $\mathbf{5 . 1 4}$ & Disclosure of criteria to evaluate Board performance & $\mathbf{1}$ \\
\hline $\mathbf{5 . 1 5}$ & CEO performance review & $\mathbf{1}$ \\
\hline $\mathbf{5 . 1 6}$ & Event Calendar & $\mathbf{1}$ \\
\hline & Total & $\mathbf{3 2}$ \\
\hline & Grand Total & $\mathbf{1 0 0}$ \\
\hline
\end{tabular}

\section{AUTHORS' BIOGRAPHY}

Syed Usman Qadri is a PhD Finance student at University of International business and Economics, Beijing China. His interest area is Auditing, Governance and Efficient market hypothesis. He has also worked as University lecturer in NUML Pakistan.

Ye Chengang is a Professor of Accounting and Vice Dean of Business School at University of International Business and Economics, Beijing. He has published many articles and books in the area of Corporate Governance, Auditing and Accounting issues.

Farooq Jamil has done MS in Finance from Pakistan. He has Interest in Corporate Governance and Auditing area.

Safwan Qadri is PhD student at Wuhan University, China. His interest area is Public Governance and Public Administration.

Citation: Syed Usman Qadri, et.al. "Corporate Governance and Disclosure Quality: Evidence from the Listed Non-Financial Firms of Pakistan". International Journal of Managerial Studies and Research (IJMSR), vol 6, no. 11, 2018, pp. 116-127. doi: http://dx.doi.org/10.20431/2349-0349.0611012.

Copyright: (C) 2018 Authors. This is an open-access article distributed under the terms of the Creative Commons Attribution License, which permits unrestricted use, distribution, and reproduction in any medium, provided the original author and source are credited. 